\title{
GAMBARAN PENILAIAN GURU TENTANG PELAKSANAAN PROGRAM USAHA KESEHATAN SEKOLAH (UKS) DI SEKOLAH DASAR NEGERI No. 060910 MEDAN TAHUN 2017
}

\author{
Connie Melva Sianipar \\ Dosen STIKes Santa Elisabeth Medan \\ e-mail: cinnie_ms@yahoo.com
}

\begin{abstract}
ABSTRAK
Latar Belakang : Program kesehatan sekolah adalah upaya untuk menumbuhkan dan mengembangkan kebiasaan sehat yang dilakukan secara terpadu melalui program pendidikan, layanan kesehatan dan perawatan kesehatan di lingkungan sekolah.

Tujuan: Tujuan dari penelitian ini adalah untuk mengidentifikasi pelaksanaan evaluasi guru tentang Program Sekolah Kesehatan (UKS) di Sekolah Dasar Negeri No.060910 Medan 2017.

Metode: Penelitian ini merupakan penelitian deskriptif dengan sampel 23 orang adalah guru sekolah dasar No. 060910 Medan 2017. Alat pengumpulan data lapangan yang digunakan adalah kuesioner.

Hasil: Hasil penelitian ini memperoleh implementasi keseluruhan program UKS yang dilaksanakan secara adil yaitu 56,5\%. Pelaksanaan UKS kegiatan pendidikan kesehatan sekolah dilakukan secara adil, yaitu $62,5 \%$, kegiatan dilakukan dengan pelayanan kesehatan yang memadai, yaitu $65,2 \%$ dan kegiatan pembinaan kesehatan lingkungan sekolah sehat berkinerja baik, yaitu 73,9\%.

Kesimpulan: Puskesmas diharapkan meningkatkan kerja sama dan kinerja mereka dengan sekolah di wilayah kerja mereka, terutama dalam meningkatkan layanan kesehatan. Puskesmas bersama sekolah perlu membahas rencana kegiatan UKS yang akan dilakukan di sekolah, sehingga dapat diatur jadwal pelaksanaan dan tugas masing-masing. Puskesmas juga diharapkan untuk bekerja sama baik dalam materi dan ide untuk meningkatkan implementasi UKS di setiap sekolah.
\end{abstract}

\section{Kata Kunci : Kesehatan Sekolah}

\begin{abstract}
Bacground: School health program is an effort to nurture and develop healthy habits conducted in an integrated manner through educational programs, health services and health care in the school environment.

Goals: The purpose of this study is to identify the implementation of teacher's evaluation about School Health Unit (UKS) program in the State Primary School No.060910 Medan 2017.

Methods: The research is a descriptive study with a sample of 23 people is a teacher of elementary school No. 060910 Medan 2017. Field data collection tool used was a questionnaire.

Results: The results of this study obtained the overall implementation of the UKS program implemented fairly that is 56.5\%. UKS implementation of school health education activities are carried out fairly, that is $62.5 \%$, the activities carried out with sufficient health care, which is $65.2 \%$ and the activities of health coaching healthy school environment performing well, which is $73.9 \%$.

Conclusion: Puskesmas are expected to improve their cooperation and performance with schools in their work areas, especially in improving health services. Puskesmas with schools need to discuss the UKS activities plan that will be done in school, so that can be arranged schedule of implementation and their respective duties. Puskesmas are also expected to work together both in materials and ideas to improve the implementation of UKS in each school.
\end{abstract}

Keywords: school health

\section{PENDAHULUAN}

Usaha Kesehatan Sekolah (UKS) adalah upaya membina dan mengembangkan kebiasaan hidup sehat yang dilakukan secara terpadu melalui program pendidikan dan pelayanan kesehatan di sekolah. UKS adalah bagian dari usaha kesehatan pokok yang menjadi beban puskesmas yang ditunjukkan kepada sekolah-sekolah (Mubarak \& Chayatin, 2009). 
Pembinaan dan pengembangan Usaha Kesehatan Sekolah merupakan salah satu upaya pemeliharaan dan peningkatan kesehatan yang ditujukan kepada peserta didik (usia sekolah), yang merupakan salah satu mata rantai yang penting dalam meningkatkan kualitas fisik penduduk. (Notoatmodjo, et.al, 2007).

Program tentang pembinaan dan pengembangan UKS di sekolah/satuan pendidikan luar sekolah dilaksanakan melalui tiga program pokok (TRIAS UKS) yang meliputi: pendidikan kesehatan, pelayanan kesehatan dan pembinaan lingkungan sekolah sehat.

Pelayanan kesehatan merupakan upaya intrakulikuler dan ekstrakurikuler. Pelayanan kesehatan merupakan upaya promotif, preventif, kuratif dan rehabilitatif yang dilakukan secara serasi terpadu terhadap peserta didik pada khususnya dan warga sekolah pada umumnya, dibawah koordinasi guru pembina UKS dengan bimbingan teknis dan pengawasan puskesmas setempat. Pembinaan lingkungan sekolah sehat mencakup lingkungan sekolah, keluarga dan masyarakat sekitar (Efendi \& Makhfudli, 2009).

Berdasarkan data departemen kesehatan tahun 2010 diperoleh bahwa masalah kesehatan yang sering terjadi pada anak sekolah dasar adalah kurang gizi sebesar $13 \%$, penyakit karies dan periodontal anak usia 5-14 tahun sebesar 21\%, kemudian diare yang menurut hasil survey subdit pada tahun 2002 dan 2003 pada 40 SD di provinsi menunjukkan prevalensi antara 2,2\%-96,3\% dan anemia pada anak 5-14 tahun sebesar 9,4\%. Pada usia anak sekolah dasar penyakit yang sering dihadapi biasanya berkaitan dengan hidup bersih dan sehat seperti kebiasaan cuci tangan pakai sabun, potong kuku, gosok gigi, dan membuang sampah sembarangan (Depkes, 2010 dalam Sasta 2013).

Dampak dari pelaksanaan UKS ini dapat dilihat dari peningkatan status kesehatan masyarakat sekolah dengan indikator menurunnya angka absensi siswa dan guru karena sakit, menurunnya kasus/siswa yang memerlukan P3K di sekolah, menurunnya kasus/siswa yang menderita kurang gizi (Notoatmodjo, dkk 2012), adanya pertambahan tinggi badan dan berat badan yang normal serta meningkatnya kebersihan peserta didik secara umum (Kementerian Pendidikan Dan Kebudayaan Direktorat Jenderal Pendidikan Dasar Jakarta, 2012).

Penelitian yang dilakukan di Sekolah Dasar Negeri Plalangan 01 dan 04 menunjukkan pendidikan kesehatan dalam pelaksanaan PHBS termasuk kategori baik sebesar $69,6 \%$, pelayanan kesehatan dalam pelaksanaan PHBS termasuk kategori baik sebesar 82,1\%, pembinaan lingkungan sekolah sehat dalam pelaksanaan PHBS termasuk kategori baik sebesar 89,3\% dan pelaksanaan perilaku hidup bersih dan sehat termasuk kategori baik sebesar 62,5\% (Kusuma, 2013).

Dari hasil penelitian pelaksanaan usaha kesehatan sekolah (UKS) di SD Negeri Kecamatan Batuan Kabupaten Sumenep didapat pendidikan kesehatan terlaksana 92,9\% yang berarti baik, dalam sub variabel pelayanan kesehatan terlaksana 58,7\% yang berarti cukup, dalam sub variabel pembinaan lingkungan kehidupan sekolah sehat terlaksana $76,2 \%$ yang berarti baik, dan pelaksanaan usaha kesehatan sekolah (UKS) SD Negeri seluruh Kecamatan Batuan Kabupaten Sumenep ditinjau dari variabel keseluruhan terlaksana $73,5 \%$ yang berarti baik (Anam, 2008).

Sedangkan dari penelitian yang dilakukan Akbar bahwa mekanisme organisasi UKS di Pusat Kegiatan Belajar Cipageran Kota Cimahi termasuk kategori cukup dengan persentase 78,33\%. Sementara di Pusat Kegiatan Belajar Masyarakat Bina Mandiri Cipageran Kota Cimahi termasuk kategori kurang dengan persentase 62,55\%, pelaksanaan program kerja UKS di Pusat Kegiatan Belajar Kota Cimahi termasuk kategori baik dengan persentase $83,49 \%$. Sementara di Pusat Kegiatan Belajar Masyarakat Bina Mandiri Cipageran kota Cimahi termasuk kategori cukup dengan persentase $77,22 \%$ dan kesediaan sarana dan prasarana UKS Pusat Kegiatan Belajar Masyarakat di Kota Cimahi dengan Pusat Kegiatan Belajar Masyarakat Bina Mandiri Cipageran Kota Cimahi termasuk kategori baik dengan persentase $66,67 \%$.

Hambatan dalam pelaksanaan UKS ini yaitu kurangnya sumber daya manusia, terbatasnya sarana dan prasarana UKS, masih belum optimalnya kerjasama lintas program maupun lintas sektor dalam pelaksanaan pembinaan dan pengembangan UKS. Serta monitoring dan evaluasi yang belum optimal. Untuk mengatasi hambatan tersebut adalah memberikan pelatihan terhadap guru yang menangani UKS (Guru Pembia UKS), pengadaan ruang UKS dan peralatan UKS, menyediakan sumber-sumber informasi mengenai UKS, mengoptimalkan fungsi tiap-tiap Tim Pembina UKS dan mengoptimalkan monitoring dan evaluasi UKS (Notoatmodjo, et.al., 2012).

Berdasarkan hasil survei awal yang dilakukan peneliti pada Sekolah Dasar Negeri No.060910 
Medan diperoleh data bahwa UKS telah dilakukan namun belum maksimal. Telah dilakukan pengamataan kesehatan lingkungan sekolah seperti pengawasan terhadap sumber air bersih, pengawasan kamar mandi/WC, penyediaan tempat sampah kering dan basah dan pengawasan terhadap kantin sekolah.

Masalah kesehatan yang sering terjadi yaitu kurangnya kesadaran akan perilaku hidup sehat dan bersih. Selain itu pelaksanaan UKS masih sangat kurang dan tidak berjalan sebagaimana mestinya serta belum adanya ruangan khusus untuk UKS. Sarana dan prasarana seperti kotak $\mathrm{P} 3 \mathrm{~K}$, alat penjaringan, alat pengukur tinggi badan belum dimanfaatkan dengan semestinya. Peran tiap-tiap pengurus belum berjalan sebagaimana mestinya. Oleh karena penilaian guru tentang UKS penting sebagai pendidik dan sebagai teladan bagi peserta didik.

\section{METODE PENELITIAN}

Desain penelitian yang digunakan adalah deskriptif, yang dilakukan dengan tujuan untuk mengidentifikasi gambaran penilaian guru tentang pelaksanaan program usaha kesehatan sekolah (UKS) pada SD Negeri No.060910 Medan pada tahun 2017. Populasi dari penelitian ini adalah Guru Sekolah Dasar Negeri No.060910 Medan 2017 sebanyak 23 orang.

Pengambilan jumlah sampel pada penelitian ini total sampling yaitu total sampel sama dengan jumlah populasi dimana jumlah populasi sebanyak 23 orang. Dengan kriteria sampel adalah dapat berkomunikasi dengan baik, dapat membaca, dapat menulis dan bersedia menjadi responden.

\section{HASIL DAN PEMBAHASAN \\ Hasil penelitian}

Desain penelitian yang digunakan adalah deskriptif, yang bertujuan untuk mengidentifikasi penilaian guru tentang pelaksanaan program usaha kesehatan sekolah (UKS) di SD Negeri No.060910 Medan Kecamatan Medan Denai tahun 2017. Responden berjumlah 23 orang dengan karakteristik responden sebagai berikut: data distribusi frekuensi karakteristik responden meliputi jenis kelamin, suku, agama, dan pendidikan terakhir. Sebagian responden berjenis kelamin perempuan yaitu sebanyak 21 orang $(91,3 \%)$, mayoritas suku batak sebanyak 17 orang $(73,9 \%)$, mayoritas beragama Kristen Protestan sebanyak 12 orang $(52,2 \%)$ dan mayoritas pendidikan terakhir yaitu S1 sebanyak 19 orang $(82,6 \%)$. a. Penilaian Guru Tentang Pelaksanaan Pendidikan Kesehatan Di Sekolah Dasar Negeri N0.060910 Medan

Hasil pelaksanaan program UKS terhadap kegiatan pelayanan pendidikan kesehatan di sekolah menunjukkan bahwa secara keseluruhan hasil kegiatan pendidikan kesehatan sekolah pada pelaksanaan program UKS di SD Negeri No.060910 Medan menyatakan bahwa pelaksanaan pendidikan kesehatan dalam kategori baik $34,8 \%$ (8 orang) dan menyatakan cukup $65,2 \%$ (15 orang).

Distribusi Frekuensi Penilaian Guru Tentang Hasil Pelaksanaan Program Usaha Kesehatan Sekolah (UKS) Dalam Kegiatan Pendidikan Kesehatan Di Sekolah Dasar Negeri No.060910 Medan

\begin{tabular}{|c|c|c|}
\hline $\begin{array}{c}\text { Pelaksanaan } \\
\text { Program UKS }\end{array}$ & Frekuensi & $\begin{array}{c}\text { Persentase } \\
(\%)\end{array}$ \\
\hline Terlaksana & 8 & 34,8 \\
\hline dengan baik & 15 & 65,2 \\
\hline $\begin{array}{l}\text { Terlaksana } \\
\text { dengan cukup }\end{array}$ & 0 & 0 \\
\hline $\begin{array}{l}\text { Terlaksana } \\
\text { dengan kurang }\end{array}$ & & \\
\hline Total & 23 & 100 \\
\hline
\end{tabular}

b. Penilaian Guru Tentang Pelaksanaan Pelayanan Kesehatan Di Sekolah Dasar Negeri No.060910 Medan

Dari penelitian yang dilakukan dalam kegiatan pelayanan kesehatan di SD Negeri No.060910 Medan, secara keseluruhan hasil dalam kegiatan pelayanan kesehatan pada pelaksanaan program UKS mayoritas responden menyatakan bahwa pelaksanaan pelayanan kesehatan dalam kategori baik $34,8 \%$ (8 orang), kategori cukup $65,2 \%$ (15 orang) dan yang mengatakan kurang $0 \%$.

Distribusi Frekuensi Penilaian Guru Tentang Hasil Pelaksanaan Program Usaha Kesehatan Sekolah (UKS) Dalam Pelayanan Kesehatan Di Sekolah Dasar Negeri No.060910 Medan

\begin{tabular}{|c|c|c|}
\hline $\begin{array}{c}\text { Pelaksanaan } \\
\text { Program UKS }\end{array}$ & Frekuensi & $\begin{array}{c}\text { Persentase } \\
(\%)\end{array}$ \\
\hline Terlaksana & 8 & 34,8 \\
\hline dengan baik & 15 & 65,2 \\
\hline $\begin{array}{l}\text { Terlaksana } \\
\text { dengan cukup } \\
\text { Terlaksana } \\
\text { dengan kurang }\end{array}$ & 0 & 0 \\
\hline Total & 23 & 100 \\
\hline
\end{tabular}


c. Penilaian Guru Tentang Pelaksanaan Pembinaan Kesehatan Lingkungan Sekolah Sehat Di Sekolah Dasar Negeri No.060910 Medan

Sedangkan hasil penelitian yang dilakukan dalam kegiatan pembinaan lingkungan sekolah sehat di SD Negeri No.060910 Medan, secara keseluruhan kegiatan pembinaan lingkungan sekolah sehat dalam pelaksanaan program UKS mayoritas responden menyatakan bahwa pelaksanaan kegiatan lingkungan di sekolah terlaksana dalam kategori baik 73,9\% (17 orang), kategori cukup 26,1\% (6 orang) dan yang mengatakan kurang $0 \%$.

Distribusi Frekuensi Penilaian Guru Tentang Hasil Pelaksanaan Program Usaha Kesehatan Sekolah (UKS) Dalam Pembinaan Kesehatan Lingkungan Sekolah Sehat Di Sekolah Dasar Negeri No.060910 Medan

\begin{tabular}{|c|c|c|}
\hline $\begin{array}{c}\text { Pelaksanaan } \\
\text { Program UKS }\end{array}$ & Frekuensi & $\begin{array}{c}\text { Persentase } \\
(\%)\end{array}$ \\
\hline Terlaksana & 17 & 73,9 \\
\hline dengan baik & 6 & 26,1 \\
\hline $\begin{array}{l}\text { Terlaksana } \\
\text { dengan cukup } \\
\text { Terlaksana } \\
\text { dengan kurang }\end{array}$ & 0 & 0 \\
\hline Total & 23 & 100 \\
\hline
\end{tabular}

d. Penilaian Guru Tentang Pelaksanaan Program Usaha Kesehatan Sekolah (UKS) Di Sekolah Dasar Negeri No.060910 Medan Kecamatan Medan Denai

Berdasarkan hasil Pelaksanaan Program Usaha Kesehatan Sekolah (UKS) secara keseluruhan, manyoritas responden menyatakan pelaksanaan program UKS sudah terlaksana dengan baik 43,5\% (10 orang), yang mengatakan pelaksanaan program UKS terlaksana dengan cukup 56,5\% (13 orang) sedangkan pelaksanaan program UKS terlaksana dengan kurang $0 \%$.

\begin{tabular}{lcc}
$\begin{array}{l}\text { Distribusi Frekuensi Penilaian Guru Tentang } \\
\text { Hasil Pelaksanaan Program Usaha Kesehatan } \\
\text { Sekolah (UKS) Di SD Negeri No.060910 Medan } \\
\text { Kecamatan Medan Denai }\end{array}$ \\
$\begin{array}{l}\text { Pelaksanaan } \\
\text { Prokram UKS }\end{array}$ & Frekuensi & $\begin{array}{c}\text { Persentase } \\
(\%)\end{array}$ \\
\hline Terlaksana & 10 & 43,5 \\
dengan baik & 13 & 56,5 \\
Terlaksana & 0 & 0 \\
dengan cukup & & \\
\hline
\end{tabular}

Terlaksana

dengan kurang

Total $23 \quad 100$

\section{PEMBAHASAN}

\section{a. Penilaian Guru Tentang Kegiatan Pendidikan Sekolah Sehat Di SD Negeri No.060910 Medan}

Berdasarkan hasil penelitian kegiatan pendidikan kesehatan sekolah pada pelaksanaan program UKS di SD Negeri No.060910 Medan didapat bahwa pelaksanaan pendidikan kesehatan dalam kategori cukup 65,2\% (15 orang). Materi pendidikan kesehatan memang sudah berjalan, pendidikan kesehatan yang selalu diberikan dengan persentase tertinggi yaitu materi manfaat sarapan pagi bagi kesehatan 82,6\% (19 orang), manfaat membiasakan buang sampah pada tempatnya $65,2 \%$ (15 orang) dan cara menjaga kebersihan lingkungan (rumah dan sekolah). Sedangkan kegiatan pendidikan kesehatan yang terendah yaitu materi bahanya minuman keras $8,7 \%$ (2 orang) dan bahanya merokok $8,7 \%$ (2 orang).

Penelitian Anam (2008) Studi Pelaksanaan Usaha Kesehatan Sekolah (UKS) SD Negeri Kecamatan Batuan Kabupaten Sumenep, pendidikan kesehatan terlaksana 92,9\% yang berarti baik dan dalam penelitian Kusuma (2013) Hubungan Antara Trias UKS Dengan Pelaksanaan PHBS Pada Murid Di Sekolah Dasar Negeri Palalangan 01 Dan Palalangan 04 Gunungpati Semarang 2013, kegiatan pendidikan kesehatan dalam kategori baik $(69,6 \%)$. Berdasarkan hasil penelitian sebelumnya sudah terlaksana dengan baik sedangkan yang ditemukan peneliti ternyata hasilnya masih cukup. Menurut Depkes RI (2003) dalam Efendi dan Makhfudli (2009) mengatakan bahwa pendidikan kesehatan adalah usaha sadar untuk menyiapkan peserta didik agar dapat tumbuh kembang sesuai, selaras, seimbang, dan sehat baik fisik, mental, sosial maupun lingkungan melalui kegiatan bimbingan, pengajaran, dan latihan yang diperlukan bagi peranannya saat ini maupun dimasa yang akan datang. Menurut Efendi dan Makfudli (2009) kegiatan pendidikan kesehatan dapat diberikan melalui kegiatan kurikuler dan ekstrakurikuler.

Hasil penelitian cukup dapat diartikan bahwa kegiatan pendidikan kesehatan memang sudah berjalan tetapi belum tercapai dengan baik sesuai yang diharapkan berbeda dengan hasil penelitian sebelumnya. Menurut peneliti hal ini disebabkan oleh kurangnya kerjasama dari antara petugas 
kesehatan, tim UKS dan pihak sekolah. Dalam penelitian sebanyak 47,8\% (11 orang) responden mengatakan petugas puskesmas datang untuk memberikan penyuluhan kadang-kadang, hal ini disebakan karena kurangnya pengorganisasian antara pihak sekolah dengan petugas puskesmas. Dengan memberikan pendidikan kesehatan secara dini, peserta didik akan lebih memahami dan menanamkan pentingnya hidup sehat. Selain itu melalui pendidikan kesehatan yang diberikan dapat meningkatkan prestasi belajar anak.

\section{b. Penilaian Guru Tentang Kegiatan Pelayanan Kesehatan Di SD Negeri N0.060910 Medan Kecamatan Medan}

Berdasarkan pelaksanaan kegiatan pelayanan kesehatan menunjukkan hasil 65,2\% tergolong cukup. Dari hasil penelitian kegiatan pelayanan kesehatan dengan persentase tertinggi yang selalu dilaksanakan yaitu selalu tersedianya meja pemeriksaan dan tempat tidur di ruangan UKS $82,6 \%$ (19 orang), sudah tersedianya obat-obat dalam lemari obat $65,2 \%$ (15 orang) dan persentase terendah yaitu pemeriksaan kesehatan yaitu meliputi gigi, mulut, mata, telinga, tenggorokan, kulit, rambut $8,7 \%$ (2 orang). Sebanyak 47,8\% (11 orang) mengatakan sekolah tidak pernah memiliki usaha kesehatan gizi sekolah (UKGS) dan $34.8 \%$ (8 orang) mengatakan tidak pernah dilakukan pencatatan dan pelaporan tentang keadaan penyakit, status gizi dan hal lainnya yang berhubungan dengan pelayanaan kesehatan.

Penelitian yang dilakukan Kusuma (2013) Hubungan Antara Trias UKS Dengan Pelaksanaan PHBS Pada Murid Di Sekolah Dasar Negeri Palalangan 01 Dan Palalangan 04 Gunungpati Semarang 2013, kegiatan pelayanan kesehatan dalam kategori baik sebesar $82,1 \%$, hasil penelitian Anam (2008) Studi Pelaksanaan Usaha Kesehatan Sekolah (UKS) SD Negeri Kecamata Batuan Kabupaten Sumenep, kegiatan pelayanan kesehatan dalam kategori cukup 58,7\%. Menurut Efendi dan Makhfudli (2009) Pelaksanan utama pada pelayanan kesehatan di sekolah atau madrasah adalah upaya peningkatan (promotif), pencegahan (preventif), pengobatan (kuratif) dan pemulihan (rehabilitatif). Yang dilakukan secara serasi dan terpadu terhadap peserta didik yang pada khususnya dan warga sekolah pada umumnya dibawah koordinasi Pembina UKS dengan bimbingan teknis dan pengawasan puskesmas setempat. Efendi dan Makfudli (2009) yang lebih diutamakan dalam upaya kesehatan di sekolah yaitu meningkatkan kesehatan dan pencegahan penyakit terutama dilaksanakan melalui kegiatan penjaringan kesehatan siswa kelas I atau yang baru masuk sekolah, pemeriksaan berkala seluruh siswa, penyuluhan kesehatan dan imunisasi.

Hasil penelitian yaitu cukup, berbeda dari hasil penelitian sebelumnya yang sudah terlaksana dengan baik. Yang berarti kegiatan pelayanan kesehatan sudah berjalan tetapi belum sesuai dengan semestinya. Hasil penelitian menunjukkan masih banyak kegiatan pelayanan kesehatan sekolah yang berjalan kadang-kadang seperti pengawasan warung dan gizi sekolah, pemeriksaan berkala setiap 6 bulan, penyuluhan kesehatan, pencegahan penyakit seperti imunisasi, pemeriksan kesehatan guru, pemeriksaan kesehatan yaitu meliputi gigi, mulut, mata, telinga, tenggorokan, kulit, rambut. Menurut peneliti untuk mencapai tujuan dari pelayanan kesehatan selain dari kegiatan peningkatan (promotif), pencegahan (preventif), pengobatan (kuratif) dan pemulihan (rehabilitatif) diperlukan latihan keterampilan teknis dalam rangka pemeliharaan kesehatan dan pembentukan peran seperti dokter kecil. Peran dokter kecil ini akan sangat mempengaruhi kegiatan pelayanan kesehatan sekolah, dokter kecil ini dapat menjadi penggerak peserta didik yang lain dan membantu dalam pemberi pertolongan pertama. Untuk kegiatan yang belum berjalan diperlukan peran guru UKS untuk melakukan pemantauan terhadap perkembangan gizi peserta didik.

\section{c. Penilaian Guru Tentang Kegiatan Pembinaan Lingkungan Sekolah Sehat Di SD Negeri No.060910 Medan}

Data hasil penelitian untuk kegiatan pembinaan lingkungan sekolah sehat di SD Negeri No.060910 sudah terlaksana dengan baik sebanyak $73,9 \%$. Persentase kegiatan tertinggi yang selalu dilaksanakan yaitu penyediaan, pemeliharaan tempat penampungan air bersih sebanyak $95,7 \%$ (22 orang) dan pengadaan dan pemeliharaan tempat pembuangan sampah sebanyak $87 \%$ (20 orang). Sedangkan persentase tertinggi untuk kegiatan yang tidak pernah dilakukan yaitu kegiatan pengawasan terhadap pencemaran lingkungan tanah, air dan udara di sekitar sekolah 52,3\% (12 orang).

Penelitian yang dilakukan oleh Kusuma (2013) Hubungan Antara Trias UKS Dengan Pelaksanaan PHBS Pada Murid Di Sekolah Dasar Negeri Palalangan 01 Dan Palalangan 04 Gunung Pati Semarang 2013 dalam kegiatan pembinaan lingkungan sekolah sehat dalam kategori baik 
89,3\% dan penelitian Anam (2008) Studi Pelaksanaan Usaha Kesehatan Sekolah (UKS) SD Negeri Kecamata Batuan Kabupaten Sumenep, dalam kategori baik 73,5\%. Menurut Notoatmodjo dkk (2012) bahwa program pembinaan lingkungan sekolah sehat dapat dilakukan melalui pembinaan lingkungan fisik seperti penyediaan air besih dan lain-lain serta pembinaan lingkungan mental dan sosial meliputi 7K (kebersihan, keindahan, kenyamanan, ketertiban, keamanan, kerindangan, kekeluargaan).

Hasil penelitian yaitu dalam kategori baik. Pemeliharaan sekolah secara fisik seperti penyediaan air bersih, pembuangan air, pemeliharaan WC, penyediaan tempat sampah, pemeriksaan kelayakan sekolah terhadap fasilitas kelas, olahraga, penerangan tetapi ada beberapa kegiatan yang tidak pernah dilakukan seperti pengawasan terhadap pencemaran lingkungan tanah air dan udara di lingkunagan sekolah. Menurut peneliti pemeliharaan sekolah secara non fisik seperti guru konselor juga sangat diperlukan untuk menangani setiap masalah peserta didik meski pihak sekolah selalu memberikan perhatian khusus terhadap anak-anak didik yang bermasalah. Kegiatan pembinaan lingkungan sekolah sehat ini dapat tercapai dengan sepenuhnya apabila setiap individu di sekolah dibiasakan untuk hidup bersih, mengajak siswa untuk berperan aktif dalam menjaga kebersihan dan keamanan sekolah meski pihak sekolah telah memiliki petugas kebersihan dan seorang petugas keamanan.

\section{d. Penilaian Guru Tentang Pelaksanaan program Usaha Kesehatan Sekolah (UKS) di Sekolah Dasar Negeri No.060910 Medan}

Berdasarkan hasil penelitian yang dilakukan

Di SD Negeri No.060910 Medan Kecamatan Medan Denai melalui kegiatan TRIAS UKS yang meliputi pendidikan kesehatan, pelayanan kesehatan dan pembinaan lingkungan sekolah sehat, secara keseluruhan terlaksana dengan baik $43,5 \%$, yang mengatakan pelaksanaan program UKS terlaksana dengan cukup 56,5\% sedangkan pelaksanaan program UKS terlaksana dengan kurang $0 \%$. Ternyata proporsi tertinggi dalam pelaksanaan program UKS yaitu cukup $56,5 \%$.

Penelitian yang dilakukan Anam (2008)

Studi Pelaksanaan Usaha Kesehatan Sekolah (UKS) SD Negeri Kecamata Batuan Kabupaten Sumenep, dalam kategori baik yaitu 73,5\%, Wijayanti (2013) dalam kategori baik 87,5\%. Mubarak dan Chayatin, (2009) mengatakan usaha kesehatan sekolah (UKS) adalah upaya membina dan mengembangkan kebiasaan hidup sehat yang dilakukan secara terpadu melalui program pendidikan dan pelayanan kesehatan di sekolah. UKS adalah bagian dari usaha kesehatan pokok yang menjadi beban puskesmas yang ditunjukkan kepada sekolah-sekolah.

Hasil keseluruhan dari penelitian ini yaitu dalam kategori cukup. Menurut peneliti keberhasilan program UKS ini sangat ditentukan oleh adanya kemitraan antara instansi terkait. Perlunya pencatatan dari setiap kegiatan UKS sehingga pemantauan dapat dilakukan. Pemantauan atau monitoring ini dilakukan untuk mengamati atau mengawasi secara terus menerus terhadap pelaksanaan kegiatan ataupun programprogram yang sudah dibuat. Dengan adanya pencatatan dapat dilakukan evaluasi untuk menilai dan membandingkan sejauh mana program UKS yang telah dicapai. Melalui evaluasi dapat menjadi masukan untuk perbaikan dan peningkatan program pengembangan UKS. Selain itu pelaporan juga sangat penting dilakukan. Semua hasil monitoring dan evaluasi dari semua kegiatan dibuat dalam bentuk tertulis sebagai lapoaran UKS.

\section{KESIMPULAN DAN SARAN Kesimpulan}

Berdasarkan hasil dan pembahasan penelitian gambaran penilaian guru tentang pelaksanaan program usaha kesehatan sekolah di sekolah dasar SD negeri No.060910 Medan di peroleh kesimpulan secara keseluruhan menurut penilaian guru tentang pelaksanaan program UKS terlaksan cukup yaitu $56,5 \%$. Penilaian guru tentang pelaksanaan UKS dalam kegiatan pendidikan kesehatan sekolah terlaksana yaitu cukup sebanyak $62,5 \%$, penilaian guru tentang kegiatan pelayanan kesehatan terlaksana dengan cukup yaitu $65,2 \%$ dan penilaian guru tentang kegiatan pembinaan kesehatan lingkungan sekolah sehat terlaksana dengan baik yaitu 73,9\%.

\section{Saran}

Dengan adanya penelitian ini diharapkan mampu memberikan masukan untuk meningkatkan program usaha kesehatan sekolah dalam rangka meningkatkan mutu pendidikan dan kesehatan pada setiap warga sekolah SD Negeri No.060910 Medan, untuk kegiatan-kegiatan yang belum terlaksana hendaknya pihak sekolah membenahi peralatan yang kurang, mengadakan pelatihan khusus untuk guru Pembina, menjalankan peran masing-masing dan 
meningkatkan kerjasama dengan Tim Pembina UKS sehingga tujuan dari UKS dapat tercapai dan untuk kegiatan yang sudah berjalan hendaknya dipertahankan dan lebih ditingkatkan lagi. Dengan adanya hasil penelitian ini dapat memberikan masukan dan gambaran bagi mahasiswa untuk dapat menjalankan perannya sebagai penyuluh dalam bidang kesehatan, mengkaji masalah kesehatan keperawatan, pengumpulan data, analisa masalah serta perumusan dan prioritas masalah dalam membantu mengembangkan tingkat kesehatan anak di sekolah dasar. Puskesmas diharapkan meningkatkan kerjasama dan kinerjanya dengan sekolah-sekolah yang ada di kawasan kerjanya terutama dalam meningkatkan pelayanan dalam hal kesehatan. Puskesmas dengan sekolah perlu membahas rencana kegiatan UKS yang akan dilakukan di sekolah, sehingga dapat diatur jadwal pelaksanaan dan tugas masing-masing. Puskesmas juga diharapkan mampu bekerjasama baik secara materi maupun ide-ide untuk meningkatkan pelaksanaan UKS di tiap-tiap sekolah.

\section{DAFTAR PUSTAKA}

Anam, Kharul, M, Z., (2008). Studi pelaksanaan usaha kesehatan sekolah (UKS) SD negeri kecamatan bantuan kabupaten sumenep. Universitas Negeri Semarang

Arikunto, S., (2006). Prosedur penelitian suatu pendekatan praktik. Jakarta: Rineka Cipta

(2009). Menajemen penelitian. Jakarta: Rineka Cipta

CDC. Health Education Classroom Questionaire. Diambil dari website http://www.cdc.gov/healthyyouth/shpps/2 006/questionnaires/pdf/envs2006question naire.pdf

Chayatin \& Mubarak, (2009). Ilmu kesehatan masyarakat: teori dan aplikasi. Jakarta: Salemba Medika

Danin, S., (2003). Riset keperawatan: sejarah \& metodologi. Jakarta: EGC

Efendi \& Makfudli, (2009). Keperawatan kesehatan komunitas: teori dan praktik dalam keperawatan. Jakarta: Salemba Medika
Effendy, N., (1998). Dasar-dasar keperawatan kesehatan masyarakat. Jakarta: EGC

Hidayat, A., (2007). Metodologi penelitian keperawatandan teknik analisa data. Jakarta: Salemba Medika

(2007). Riset keperawatan dan teknik penulisan ilmiah. Jakarta: Salemba Medika

Konsultan Manajemen Nasional, (2010). Petunjuk teknis kegiatan kesehatan sekolah (UKS) dalam PNPM mandiri pedesaan. Jakarta: PNPM Mandiri

Kusuma, L. T., (2013). Hubungan antara trias UKS dengan pelaksanaan PHBS pada murid di sekolah dasar negeri palalangan 01 dan palalangan 04 gunungpati semarang 2013. Program Sarjana. Fakultas Kesehatan

Martunus, (2013). Peran pelaksana usaha kesehatan sekolah dalam kesehatan anak SD Negeri No.026 simpang tiga kecamatan loa janan ilir. e-Journal Ilmu Sosial

Muzaklroh, U, et.al. (2004). Kemitraan antara puskesmas dengan sekolah dasar dalam kegiatan usaha kesehatan sekolah (UKS) studi kasus di wilayah kerja puskesmas jabon, kecamatan jombang, kabupaten jombang jawa timur tahun 2000. Buletin Penelitian Sistem Kesehatan, Vol 8

Notoatmodjo, Hassan, Hadi, \& Krianto, T., (2012). Promosi kesehatan di sekolah. Jakarta: Rineka Cipta

Notoatmodjo, S., (2010). Metodologi penelitian kesehatan. Jakarta: Rineka Cipta

Purba, S. W., (2014). Pelaksanaan program usaha kesehatan sekolah (UKS) pada sekolah dasar negeri di wilayah kerja puskesmas kecamatan dolok sanggul kabupaten humbang hasundutan.USU

Riyanto, A., (2011). Aplikasi metodologi penelitian kesehatan. Yogyakarta: Nuha Medika 
Sugyono, (2010). Statistika untuk penelitian. Bandung: CV Alfabeta.

Sumijatun, Suliswati, Payapo, Maruhawa, J. \& Sumartini, M., (2006). Konsep dasar keperawatan komunitas. Jakarta: EGC

Tim Pembina UKS. Usaha kesehatan sekolah (UKS) tingkat sekolah dasar (SD/MI).
Diambil

dari websitehttp://www.mebermutu.org/admin $1 \quad$ lampiran/pedoman-pembinaanuks.pdfdibukapadatanggal 30 April 2014

Wijayanti T. (2007). Dampak psikologis pada perempuan penderita kanker payudara. Semarang: Universitas Katolik Soegijapranata 